\section{Distribution of Cadmium in North Atlantic Deep-Sea Sediments}

THERE is little information available on the concentration of the volatile, biologically toxic, element cadmium in deep-sea sediments. We present here some data on its distribution in a series of North Atlantic deep-sea sediments.

The material analysed, which included associated sea salt, was taken from the top portions of various NAVADO ${ }^{1}$ cores, and $\mathrm{Cd}$ was determined on a dithizone extract of a digest of the sample using an atomic absorption carbon rod atomization technique. Sampling locations and the Cd contents of the cores are given in Table 1. The more important findings are,

Table 1 Sampling Location and Analytical Data from North Atlantic Deep-Sea Sediments

\begin{tabular}{|c|c|c|c|c|}
\hline \multirow[b]{2}{*}{ Core } & \multirow[b]{2}{*}{ Location } & \multirow{3}{*}{$\begin{array}{c}\text { Total } \\
\text { carbonate } \\
\text { content } \\
\text { (wt. \%) } \\
54\end{array}$} & \multicolumn{2}{|c|}{ Cd content (p.p.b.) } \\
\hline & & & $\begin{array}{c}\text { Total } \\
\text { sediment }\end{array}$ & $\begin{array}{c}\text { Carbonate- } \\
\text { free } \\
\text { basis }\end{array}$ \\
\hline C 2 & $16^{\circ} 02^{\prime} \mathrm{N}, 29^{\circ} 43^{\prime} \mathrm{W}$ & & 120 & 260 \\
\hline E 3 & $22^{\circ} 04^{\prime} \mathrm{N}, 35^{\circ} 34^{\prime} \mathrm{W}$ & 1 & 40 & 40 \\
\hline E 6 & $21^{\circ} 48^{\prime} \mathrm{N}, 56^{\circ} 41^{\prime} \mathrm{W}$ & 1 & 40 & 40 \\
\hline E 7 & $22^{\circ} 06^{\prime} \mathrm{N}, 69^{\circ} 05^{\prime} \mathrm{W}$ & 5 & 275 & 290 \\
\hline F 1 & $25^{\circ} 06^{\prime} \mathrm{N}, 70^{\circ} 22^{\prime} \mathrm{W}$ & 12 & 315 & 360 \\
\hline F 3 & $25^{\circ} 12^{\prime} \mathrm{N}, 57^{\circ} 24^{\prime} \mathrm{W}$ & 10 & 200 & 220 \\
\hline $\mathrm{F} 4 *$ & $24^{\circ} 55^{\prime} \mathrm{N}, 49^{\circ} 15^{\prime} \mathrm{W}$ & 58 & 300 & 710 \\
\hline F $5 *$ & $24^{\circ} 49^{\prime} \mathrm{N}, 39^{\circ} 28^{\prime} \mathrm{W}$ & 77 & 215 & 935 \\
\hline F 7 & $25^{\circ} 11^{\prime} \mathrm{N}, 19^{\circ} 44^{\prime} \mathrm{W}$ & 66 & 315 & 925 \\
\hline G 3* & $27^{\circ} 41^{\prime} \mathrm{N}, 49^{\circ} 10^{\prime} \mathrm{W}$ & 51 & 295 & 600 \\
\hline G 4 & $27^{\circ} 49^{\prime} \mathrm{N}, 65^{\circ} 54^{\prime} \mathrm{W}$ & 2 & 490 & 495 \\
\hline H 6 & $30^{\circ} 53^{\prime} \mathrm{N}, 23^{\circ} 08^{\prime} \mathrm{W}$ & 63 & 190 & 515 \\
\hline I 1 & $33^{\circ} 52^{\prime} \mathrm{N}, 12^{\circ} 56^{\prime} \mathrm{W}$ & 59 & 285 & 695 \\
\hline J 2 & $36^{\circ} 39^{\prime} \mathrm{N}, 63^{\circ} 10^{\prime} \mathrm{W}$ & 42 & 250 & 435 \\
\hline J 3 & $37^{\circ} 46^{\prime} \mathrm{N}, 55^{\circ} 00^{\prime} \mathrm{W}$ & 32 & 305 & 450 \\
\hline J $4 *$ & $37^{\circ} 27^{\prime} \mathrm{N}, 38^{\circ} 00^{\prime} \mathrm{W}$ & 89 & 115 & 1,035 \\
\hline$J 5^{*}$ & $37^{\circ} 15^{\prime} \mathrm{N}, 27^{\circ} 40^{\prime} \mathrm{W}$ & 74 & 230 & 885 \\
\hline K 6 & $39^{\circ} 14^{\prime} \mathrm{N}, 69^{\circ} 19^{\prime} \mathrm{W}$ & 35 & 95 & 145 \\
\hline L $4 *$ & $43^{\circ} 03^{\prime} \mathrm{N}, 23^{\circ} 16^{\prime} \mathrm{W}$ & 55 & 300 & 665 \\
\hline L 5 * & $43^{\circ} 01^{\prime} \mathrm{N}, 17^{\circ} 14^{\prime} \mathrm{W}$ & 88 & 150 & 1,230 \\
\hline M $3 *$ & $45^{\circ} 59^{\prime} \mathrm{N}, 32^{\circ} 11^{\prime} \mathrm{W}$ & 45 & 250 & 455 \\
\hline W 1 & $49^{\circ} 10^{\prime} \mathrm{N}, 41^{\circ} 32^{\prime} \mathrm{W}$ & 13 & 100 & 115 \\
\hline N 2* & $48^{\circ} 52^{\prime} \mathrm{N}, 34^{\circ} 12^{\prime} \mathrm{W}$ & 32 & 580 & 850 \\
\hline N 3* & $48^{\circ} 40^{\prime} \mathrm{N}, 24^{\circ} 31^{\prime} \mathrm{W}$ & 20 & 370 & 460 \\
\hline N 4 & $48^{\circ} 55^{\prime} \mathrm{N}, 17^{\circ} 12^{\prime} \mathrm{W}$ & 60 & 265 & 660 \\
\hline O 2 & $52^{\circ} 00^{\prime} \mathrm{N}, 17^{\circ} 50^{\prime} \mathrm{W}$ & 13 & 190 & 220 \\
\hline $\mathbf{P} 2$ & $55^{\circ} 09^{\prime} \mathrm{N}, 22^{\circ} 45^{\prime} \mathrm{W}$ & 49 & 190 & 380 \\
\hline P $3 *$ & $55^{\circ} 56^{\prime} \mathrm{N}, 35^{\circ} 30^{\prime} \mathrm{W}$ & 45 & 300 & 545 \\
\hline Q 1 & $57^{\circ} 59^{\prime} \mathrm{N}, 10^{\circ} 04^{\prime} \mathrm{W}$ & 44 & 40 & 70 \\
\hline Q 3* & $57^{\circ} 56^{\prime} \mathrm{N}, 29^{\circ} 08^{\prime} \mathrm{W}$ & 57 & 220 & 510 \\
\hline R 2 & $60^{\circ} 54^{\prime} \mathrm{N}, 13^{\circ} 05^{\prime} \mathrm{W}$ & 50 & 40 & 80 \\
\hline R 3* & $60^{\circ} 58^{\prime} \mathrm{N}, 20^{\circ} 58^{\prime} \mathrm{W}$ & 26 & 145 & 195 \\
\hline R $4 *$ & $61^{\circ} 04^{\prime} \mathrm{N}, 32^{\circ} 30^{\prime} \mathrm{W}$ & 32 & 320 & 470 \\
\hline S $3 *$ & $64^{\circ} 02^{\prime} \mathrm{N}, 28^{\circ} 57^{\prime} \mathrm{W}$ & 5 & 190 & 200 \\
\hline T 3 & $68^{\circ} 36^{\prime} \mathrm{N}, 06^{\circ} 55^{\prime} \mathrm{W}$ & 36 & 200 & 310 \\
\hline Averag & ; all deep-sea sedimen & & & 225 \\
\hline Averag & ; deep-sea clays $(<30$ & $\%$ total ca & nate) & 215 \\
\hline Averag & deep-sea carbonates & $>30 \%$ to & carbonate) & 235 \\
\hline
\end{tabular}

* Sediments from the Mid-Atlantic Ridge and ridge flank system.

first, the average Cd content of the North Atlantic deep-sea sediments analysed is 225 p.p.b. (p.p. $10^{9}$ ). This is close to the average of 271 p.p.b. Cd given for two deep-sea sediments from the North Atlantic ${ }^{2}$. Second, the average Cd content of our samples containing $>30 \%$ total carbonate is 235 p.p.b., compared to 215 p.p.b. for samples containing $<30 \%$ total carbonate; there is little difference, on average, between the $\mathrm{Cd}$ contents of sediments containing a large proportion of carbonate shell material and those consisting predominantly of lithogenous components.

We have suggested ${ }^{3}$ that because deep-sea carbonates and deep-sea clays contained similar amounts of $\mathrm{Hg}$ it was incorrect to use calculated carbonate-free values to assess geographical trends in the distribution of this element. Subsequent analyses showed that the relatively high $\mathrm{Hg}$ content of carbonate shell material justified this approach. To investigate further the association between $\mathrm{Cd}$ and carbonate material a number of shells were separated from 12 of the deep-sea sediments; the range of $\mathrm{Cd}$ contents in the shells was $<5$ to 120 p.p.b., with an average of 55 p.p.b. Our material consisted predominantly of the shells of foraminifera, and the average of 55 p.p.b. Cd may be compared with that of 28 p.p.b. found in the shells of near-shore marine organisms ${ }^{2}$. It is apparent, therefore, that although some carbonate shell can contain $\sim 100$ p.p.b. Cd, shell debris in general acts as a diluent on the $\mathrm{Cd}$ present in non-carbonate components, such as the clay minerals.

Third, both in the total sediment samples, and on a calculated carbonate-free basis, there is a tendency for higher Cd contents to be found in mid-ocean areas. For example, the average carbonate-free $\mathrm{Cd}$ content for these samples from the MidAtlantic Ridge and ridge flank system (see Table 1) is 650 p.p.b., compared to 335 p.p.b. for sediments from other localities. Sediments from the mid-ocean ridge system contain, on average, more total carbonate than those from other localities. The average $\mathrm{Cd}$ content of shell material from ridge samples (55 p.p.b.) is the same as that from non-ridge samples (55 p.p.b.), and if allowance is made for carbonateassociated $\mathrm{Cd}$ it is apparent that the non-carbonate fractions of mid-oceanic ridge sediments are significantly richer in $\mathrm{Cd}$ than those from other Atlantic deep-sea localities.

We thank Drs D. Taylor-Smith and A. S. G. Jones, Marine Science Laboratory, University College of North Wales, for supplying the core material.

\section{S. R. Aston \\ R. CHESTER \\ A. GRIFFITHS \\ J. P. RILEY}

Department of Oceanography,

The University,

Liverpool L69 $3 B X$

Received July 20, 1972.

${ }^{1}$ Buchan, S., Dewes, F. C. D., Jones, A. S. G., McCann, D. M., and Taylor-Smith, D., Geol. Dept. No. 71-1 (Marine Sci. Labs., Univ. Coll. North Wales, 1971).

2 Mullin, J. B., and Riley, J. P., J. Mar. Res., 15, 103 (1956).

3 Aston, S. R., Bruty, D., Chester, R., and Riley, J. P., Nature Physical Science, 237, 125 (1972).

\section{Cathodoluminescence in Deformed Diamond}

WE describe here, for the first time, changes in the cathodoluminescence of diamond, caused by deformation. Fig. 1a scanning electron micrograph-shows part of a polished (100) surface of a diamond. This surface had been prepared for another experiment by polishing in the [001] direction with $0-1 \mu \mathrm{m}$ powder, and then in the [010] direction with a nominal 4-8 $\mu \mathrm{m}$ powder. The surface damage shown in Fig. 1 appeared during polishing with the coarser powder. The area is approximately square in outline with sides about $30 \mu \mathrm{m}$ long, but two of the four sides appear fore-shortened, as the surface was tilted in the microscope to bring out detail. The damage is similar to the ring cracks produced on diamond surfaces by loading them with a ballbearing. An analysis of these ring cracks ${ }^{1,2}$ shows that the damage consists primarily of a cone crack, spreading outward and downward from the surface, which is held open by debris when the load is removed. The stone is thus left in a state of elastic strain, particularly in the region within the surface crack.

We also viewed the same surface in the cathodoluminescence mode of the scanning microscope, by observing photon emission from the diamond. This particular diamond (unlike many 